\title{
DEVELOPMENT OF A METHODOLOGY FOR MANAGING OF SERVICE PACKAGES SUPPLY DIFFERENTIATION IN THE MODERN TOURIST MARKET
}

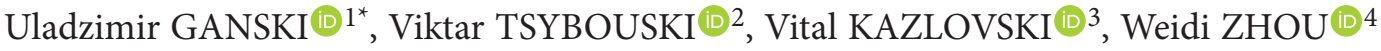 \\ ${ }^{1,2}$ Institute of Entrepreneurial Activity, Minsk, Belarus \\ ${ }^{3}$ Yanka Kupala State University, Grodno, Belarus \\ ${ }^{4}$ Central China Normal University, Wuhan, China
}

Received 2 April 2020; accepted 4 May 2020

\begin{abstract}
The modern tourism market is characterized by an increased struggle of tour operators for consumers and meeting their needs. Today a condition for the successful functioning of travel companies is the increasing differentiation of supply and the expansion of the range of package tours and services. However, any solutions should be preceded by their theoretical development. During the course of article writing, the authors set themselves as a goal is an analytical understanding of the methodology for managing the differentiation of package tours and services in order to solve the problem of ensuring high consumer value based on their differentiation by consumer characteristics, regardless of the type of services package and the purpose of travel. The article substantiates the feasibility of managing the differentiation of package tours as a source of increasing their consumer value in the dynamics of consumer expectations, and also presents a new author's methodology for studying the process of differentiation of package tours. The results of study are of theoretical and practical significance. They can be used as a basis for further scientific research, and they can also be used in the practical activities of tour operators to differentiate their offer in the market and thereby increase their competitiveness and increase profits.
\end{abstract}

Keywords: tourism, market, supply, tour operator, package tour, product differentiation, tourist enterprise.

JEL Classification: B41, Z30.

\section{Introduction}

In the globalized world economy, the development of national tourism is associated with the promotion of tourist products to new segments of the tourist market. This process is complicated by the instability of the external environment, the existing signs of monopolization of the segment of tourist operators and increased competition among travel agents. Dynamism of consumer expectations, asymmetry of information about the quality and consumer properties of a tourist product determine the priority of better coverage of the needs of consumers with specific requirements through the formation of an individualized tourist offer; increasing the role of competitive interaction of business entities, which encourages the acquisition of competitive advantages that ensure the competitiveness of tourism enterprises. These arguments lead to the need of development of methodical approaches to the management of differentiation of tourism products as an element of competitive strategy because the tourist product as a commodity peculiar dual nature: first, the origin of such goods is associated with the entity for which the tourism product is a product to meet consumer needs; second, the components of consumer value of tourist product materialists thanks to well-formed by tour operator package travel services. Accordingly, it is due to the differentiation of a tourist product by different consumer characteristics that unique market properties and competitive advantages appear which increase its consumer value in the context of maximizing consumer satisfaction. In this regard, tour operators and travel agents, in an effort to maintain and expand their market share, develop and implement strategic plans and operational actions related to the development of new consumer segments, the organization of additional sales channels, and improving the efficiency of the existing system for the sale of tourist products in conditions of an oversupply in the tourist market.

In the conditions of severe competition in the tourist market, a kind of guarantee of economic stability of the functioning of tourist enterprises is the loyalty of consumers as a result of systematic and complete satisfaction of

*Corresponding author. E-mail: ganski@tut.by 
their expectations. It is clear that a loyal consumer segment can only be formed if tourism products are differentiated for different consumer segments. The growth of international tourist flows continued to outpace economic growth until the beginning of 2020 .

International tourist arrivals in 2019 worldwide increased by $4 \%$ and reached 1.5 billion people. 2019 was another year of strong growth, although slower than the record pace of $2017(+6 \%)$ and subsequent $2018(+6 \%)$. Consumer demand was slower mainly in the OECD countries and especially in Western Europe. In all regions of the world, there was an increase in the number of arrivals. Growth was led by the Middle East $(+8 \%)$, followed by Asia and the Pacific $(+5 \%)$. International arrivals to Europe and Africa (both $+4 \%$ ) increased in line with the global average, while the Americas saw a 2\% increase (World Tourism Organization, 2020). As for the main source markets, France reported the strongest growth in international tourism spending among the world's ten largest markets, while the US was the first in global growth in absolute terms. Based on the trends observed at the time, the economic Outlook and the confidence index, UNWTO had previously forecast an increase in the number of international tourist arrivals around the world in 2020 of between $3 \%$ and $4 \%$. However, it is already clear that these optimistic forecasts will not come true. Global tourism is facing a major crisis and serious challenges. Over the past year, Brexit-related uncertainty, geopolitical and trade tensions, and a slowdown in the global economy have weighed on economic growth. 2019 was also a year of major changes in the tourism market due to the collapse of the travel company Thomas Cook and several low-cost airlines in Europe (World Tourism Organization, 2020). However, 2020 promises to be a year of real huge challenges for all tourism businesses around the world due to the COVID-19 coronavirus pandemic. Only the strongest tour operators will remain on the market, which will be able to diversify their offer in time and adapt to the new complex conditions of the changed market.

It is also worth noting that the feature of the modern tourist market is not only an oversaturation of the same type of tourist products, among which the consumer must make a choice, but also an overabundance of information, the presence of which is the key to making the right decisions. The problem, it turns out, is that the consumer cannot always rationally choose a tourist product that will provide a high level of satisfaction of the expected needs. Therefore, from the point of view of the manufacturer of tourist products, it is extremely important to understand what characteristics of tourist products determine their consumer value and how it is related to the formation of a tourist offer. This is not just a factor of effective functioning of the company, but a condition for its survival in the difficult conditions of the impending global crisis.

The goal of article is to expand the methodological basis for managing the differentiation of tourist services packages to solve the problem of ensuring their high consumer value based on their differentiation by consumer characteristics, regardless of the type of tourism and the purpose of travel.

\section{Literature review}

The lack of a sufficiently systematized generally recognized concept of differentiation of tourist products and tools for their analysis determines the feasibility of research on the content, forms and features of differentiation of tourist products and services. Differentiation of tourist products and services is defined as a variation of parameters that are perceived by consumers as a variety or characterize variations in their consumer characteristics.

This aspect is reflected in the scientific works of such classics of economics as Marshall (2013), Cournot (2008), Jevons (1871), Edgeworth (1996), Sraffa (1975), Chamberlin (1957) and Robinson (1969), who viewed differentiation as a set of certain product characteristics. Stigler (1983) and Sutton (2001) investigated vertical product differentiation, in which price competition is the dominant form of interaction between business entities. Lancaster and Jobber (2009) developed the theory of spatial differentiation of a product as a set of characteristics that are arguments for the utility function (value) for consumers, which means that the highest "concentration" of consumer characteristics is the highest quality of the product. Hotelling (1932) and Salop (1981) analyzed horizontal differentiation, in which the dominant factor is the location of the seller and buyer in the economic space. Significant results of research on product differentiation are reflected in the scientific works of such modern researchers as Porter (1998), Dussauge and Garrette (1999). Among the main areas of research of these scientists are the analysis of the process of differentiation of products and services through the effectiveness of marketing and pricing policies, advertising, brand positioning, etc.

Economists have been studying the differentiation of products and services for a long time. Popular in this area of knowledge were the works of Smith (1956) and Fisher (1991). Authors try to take into account the peculiarities of post-industrial society, market behavior of modern buyers and changes in their motivations in the process of differentiation of products and services. These are, for example, authors such as Naipaul and Parsa (2000), Gebauer et al. (2011).

Contemporary authors among other things study the issues of tourism product development and product diversification in destinations (Benur \& Bramwell, 2015), questions of choosing between diversification and specialization (Sheng, 2011), effects of diversification on smart specialization (Weidenfeld, 2018), hotel differentiation issues (Erkus-Öztürk, 2016), evolutionary analysis (García \& Tugores, 2013), deeper connections (Lejarraja \& Walkenhorst, 2007), etc. Recently, studies of cases and experiences of successful differentiation, both national and regional and urban destinations, have become quite popular. These are, for example, quite interesting articles by Romão and Nijkamp (2019), Erkuş-Öztürk and Terhorst (2018), Romão et al. (2015), Phillips (2014), Farmaki (2012), etc.

Without reducing the significance of scientific improvements, it should be noted that the problem of managing the differentiation of tourist service packages based on the allocation of their consumer characteristics, which are the 
basis for generating high consumer value of the packages offered by tour operators, unnoticed by scientists.

\section{Methodology}

In accordance with the goals of this study, which aims to expand the methodological bases of differentiation of package tours to solve the problem of ensuring high consumer value of package tours and tourist services based on their differentiation by consumer characteristics, regardless of the type of tourist package and the purpose of travel, this study used samples of package tour consumers from not coastal regions of Europe (Belarus) and Asia (Hubei province, China) in 2019. This was intended by the authors to ensure the representativeness and reliability of the results obtained, as well as the universality of the developed methodology on an international scale. The first group (European) consisted of 78 people who had purchased any package tour abroad at least twice in the past three years, and the second group (Asian) included
122 consumers who had left their country at least once in the past two years as a part of organized tour group. They were selected using a convenient sampling method, receiving a total of 200 responses. Based on the results of interviewing consumers of tourist products, calculations were made that allowed the authors to determine the significance of certain factors of differentiation of tourist services and package tours.

\section{Results}

According to the results of the study of theoretical developments known to date, it is found that in the conditions of frequent changes in consumer preferences, it is advisable to monitor the factors that affect the differentiation of packages of tourist services and the dynamics of its modification. To implement this analytical task, Figure 1 presents a structural model for managing the differentiation of the offer of tourist services, and then the article reveals the essence of each of the research stages shown.

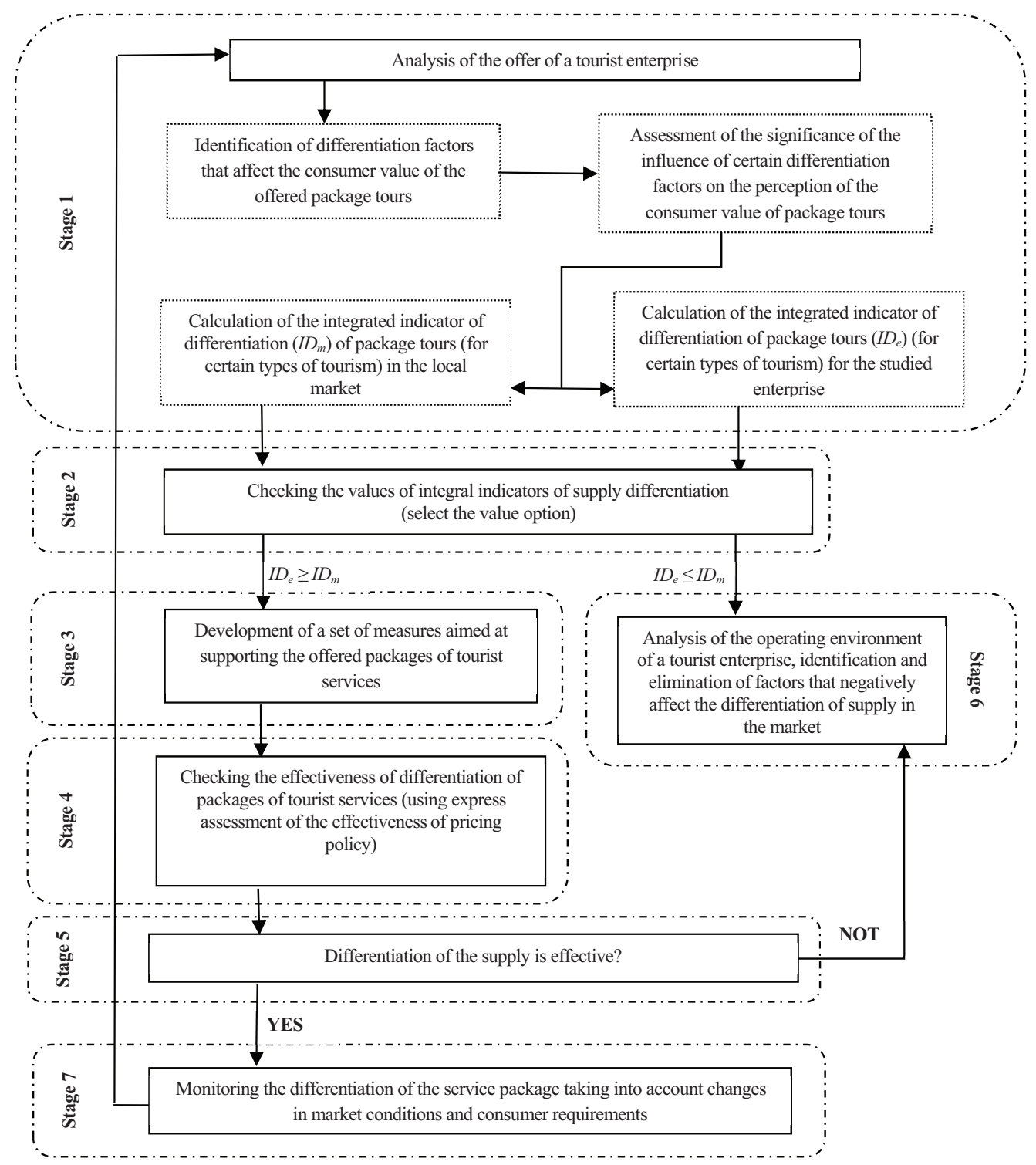

Figure 1. Structural model for managing the differentiation of the supply of a package of tourist services 
According to the developed procedure at stage $1 \mathrm{ex}-$ plores the entrepreneurial environment of functioning of tourist enterprises and a range of travel services for the purpose of calculation of integral index of differentiation $\left(I D_{m}\right)$ packages of travel services (for each type of tourism) on the local market and increased differentiation of tourism packages $\left(I D_{e}\right)$ (for certain types of tourism for the enterprise). To assess the impact of factors of differentiation of travel packages, it is advisable to use a method according to which the impact is evaluated by a certain number of points. The amplitude of points that characterize the final result should not be large to ensure the accuracy of the expert assessment. Therefore, the authors limited the differentiation of evaluation parameters to a five-point scale. Factors of differentiation of packages of tourist services that characterize variations in consumer characteristics based on the results of interviewing consumers are defined as: quality, functionality of packages of tourist services, flexibility of pricing policy, relationships with consumers in the format of a customer base, professional skills of managers, availability of loyalty programs, brand of the enterprise in the tourist market, information and advertising support for search for tours.

To determine the significance of individual factors of differentiation of packages of tourist services, the authors developed a scale of ranks (Table 1). To obtain a normalized value of the significance level (specific weight) of a single factor, it is necessary to recalculate expert estimates using the classical formula:

$$
z_{i}=\frac{\sum_{j=1}^{m} Z_{i, j}}{\sum_{i=1}^{n}\left(\sum_{j=1}^{m} Z_{i, j}\right)}
$$

Table 1. Scale of assessment of the impact of factors of differentiation of packages of tourist services on their consumer value

\begin{tabular}{|c|c|c|c|}
\hline $\begin{array}{l}\text { Scale } \\
\text { value }\end{array}$ & Impact & Impact degree & Rank \\
\hline 0 & No impact & - & - \\
\hline 1 & $\begin{array}{l}\text { Insignificant (negatively } \\
\text { affects, tends to worsen) }\end{array}$ & Insignificant & 1 \\
\hline 2 & $\begin{array}{l}\text { Temperate (negatively } \\
\text { affects, there is no tendency } \\
\text { to change it) }\end{array}$ & Lower-middle & 3 \\
\hline 3 & $\begin{array}{l}\text { Considerable (negatively } \\
\text { affects, there is a tendency } \\
\text { to improve) }\end{array}$ & Middle & 5 \\
\hline 4 & $\begin{array}{l}\text { Important (positively } \\
\text { affects, tends to deteriorate) }\end{array}$ & Upper-middle & 7 \\
\hline 5 & $\begin{array}{l}\text { Very strongly (positively } \\
\text { affects, there are no trends } \\
\text { to change it) }\end{array}$ & $\begin{array}{l}\text { Significant (there } \\
\text { is an obvious } \\
\text { relationship } \\
\text { between diffe- } \\
\text { rentiation and } \\
\text { consumer value) }\end{array}$ & 9 \\
\hline
\end{tabular}

where $z_{i}$ is the normalized value (specific weight) of the factor; $Z$ is the expert assessment of the significance of the $i$ th factor on a five-point scale; $n$ is the number of weighed factors of differentiation of packages of tourist services; $m$ is the number of experts (respondents).

Ranks 2, 4, 6, 8 are intermediate values between two neighboring values that are used in the compromise version.

The results obtained must be checked for consistency in order to eliminate possible errors during data processing. To determine the degree of consistency of expert assessments, the concordance coefficient is calculated:

$$
W=\frac{S}{\frac{1}{12 m^{2}}\left(n^{3}-n\right)-m \cdot \sum_{j=1}^{m} T_{j}} .
$$

At the same time

$$
T_{j}=\frac{1}{12} \sum_{j=1}^{m}\left(t_{j}^{n}-t_{j}\right)
$$

where $t_{j}$ is the number of identical ranks in the $j$ th row; $S$ is the deviation of the sum of rank squares from the average rank squares; $n$ is the number of factors that differentiate travel packages; $m$ is the number of observations.

The final assessment of the impact of a single factor is calculated as the arithmetic average of individual expert assessments:

$$
F_{i}=\frac{\sum_{i=1}^{m} f_{i}}{m},
$$

where $F_{i}$ is the final value of the factor assessment; $f i$ is the value of the factor estimation for an individual expert; $m$ is the number of experts involved (respondents).

The integrated indicator of differentiation of tour operator's packages of tourist services (IDe) reflects the combined influence of factors on their consumer value and is calculated using the formula:

$$
I D_{e}=\frac{\sum_{i=1}^{n} F_{i} \cdot z_{i}}{f_{\max }},
$$

where $f_{\max }$ is the maximum possible value of expert assessment of the influence of differentiation factors.

Based on the results of interviewing consumers of travel packages, which was conducted in the framework of this study, calculations were made that allow us to recommend indicators of the significance of individual factors of differentiation of travel packages (Table 2).

At the stage of checking the values of integral indicators of differentiation of packages of tourist services it is proposed to compare the level of differentiation of packages of tourist services of each individual tour operator with similar indicators in the local market. The development stage of complex activities to support differentiation of tourism packages focused on the development and implementation of activities for a specific operator by results 
Table 2. Recommended indicators of the significance of individual factors of differentiation of packages of tourist services

\begin{tabular}{|l|c|}
\hline \multicolumn{1}{|c|}{ Factor } & $\begin{array}{c}\text { Significance } \\
\text { of the factor }\end{array}$ \\
\hline Quality of tourist service & 0.1639 \\
\hline Flexible pricing policy & 0.1541 \\
\hline $\begin{array}{l}\text { Functional content of the package of tourist } \\
\text { services }\end{array}$ & 0.1344 \\
\hline Professional competence of managers & 0.1311 \\
\hline $\begin{array}{l}\text { Customer relations in the customer database } \\
\text { format }\end{array}$ & 0.1148 \\
\hline Availability of loyalty programs & 0.1115 \\
\hline $\begin{array}{l}\text { Information and advertising support for sales } \\
\text { activities }\end{array}$ & 0.0984 \\
\hline Tour operator's brand in the tourist market & 0.0918 \\
\hline Integral indicator of differentiation & 1.0 \\
\hline
\end{tabular}

of check of values of integral indicators of differentiation of tourism packages.

The need to implement the stage of checking the effectiveness of differentiation of packages of tourist services is related to the fact that the consumer value is determined by the marginal price of demand. For managers of tour operators, there is an objective need to track the correctness of decisions made regarding the price of travel packages and assess its impact on consumer value.

For the effectiveness of measures to differentiate packages of tourist services, a rapid assessment method is proposed, based on the calculation of the values of the variable cost coefficient $\left(k_{1}\right)$ and the gross profit coefficient $(k 2)$. The coefficient of variable expenses is equal to the ratio of variable expenses (per unit or for the entire volume of a package of tourist services sold) to the price or revenue from sales:

$$
k_{1}=\frac{\sum Q \cdot C_{v}^{u}}{\sum Q \cdot P}
$$

where $Q$ is the volume of tourist service packages sold; $C_{v}^{u}$ is the variable costs per unit package of tourist services; $P$ is the price of a package of tourist services.

The gross profit ratio is equal to the ratio of gross or margin profit to the price or revenue from the sale of tourist services:

$$
k_{2}=\frac{G r P}{\sum Q \cdot P},
$$

where $\operatorname{GrP}$ is the gross profit.

Next we need to consider the relationship of coefficients:

$$
\sum Q \cdot P=\sum Q \cdot C_{v}^{u}+G r P,
$$

from what

$$
\frac{\sum Q \cdot P}{\sum Q \cdot P}=\frac{\sum Q \cdot C_{v}^{u}}{\sum Q \cdot P}+\frac{G r P}{\sum Q \cdot P} \rightarrow k_{1}+k_{2}=1,
$$

$$
\begin{aligned}
& k_{1}=\frac{C_{v}^{u}}{P}, \\
& k_{2}=\frac{\sum Q\left(P-C_{v}^{u}\right)}{\sum Q \cdot P}=\frac{P-C_{v}^{u}}{P} .
\end{aligned}
$$

A more effective option is one where $k_{1}$ is quantitatively smaller, i.e. $k_{1} \rightarrow 0$, and $k_{2}$ is larger, i.e. $k_{2} \rightarrow 1$. These coefficients will allow you to compare and evaluate different pricing options when making decisions on differentiating travel packages, especially when resource opportunities are limited in the context of rapid changes in the tourist market.

\section{Conclusions}

A methodological approach to managing the differentiation of the supply of a package of tourist services, consisting of seven stages, has been developed: analysis of the supply of a tourist enterprise; checking the values of integral indicators of supply differentiation; development of a set of measures aimed at supporting the offered packages of tourist services; checking the effectiveness of differentiation of packages of tourist services using rapid assessment of the effectiveness of pricing policy; determining whether supply differentiation is effective; analysis of the operating environment of a tourist enterprise, identification and elimination of factors that negatively affect the differentiation of supply in the market; monitoring the differentiation of the service package taking into account changes in market conditions and consumer requirements.

The analytical methods of managing the process of differentiation of packages of tourist services procedures proposed by the authors of the article will allow tourism enterprises: take into account the factors of differentiation that affect the formation of consumer demand; influence the consumer characteristics of travel packages regardless of the type of tourism and the purpose of travel; form management decisions aimed at improving the consumer characteristics of travel packages in key areas of consumer value formation, which will reduce the backlash between the expected and received consumer properties of a package of travel services; ensure the improvement of business processes for the design, development and organization of consumption of packages of tourist services, which entails economic benefits that can be obtained by a tourist enterprise as a result of increasing the level of customer satisfaction; forecast the dynamics of the tourism market by type of tourism; assess the potential risks of differentiating travel packages; reasonably distribute and use all types of resources of the tourist enterprise-material, financial, labor and intangible assets, which will allow the enterprise to reach the highest level of generating consumer value of tourist services for their promotion to new market segments. 


\section{Limitations and future research directions}

Te study is not without limitations. When preparing the article, the authors focused mainly on large tour operators that sell highly standardized package tours. In addition, 2020 promises to be extremely difficult for the world tourism market, the number of international tourist arrivals will sharply decrease, and many destinations will lose their tourists and profits. It is possible that after the recovery, the tourist services market will undergo serious changes, which are very difficult for us to predict today. This may require clarification of the significance of individual factors of differentiation of tourist services packages. In addition, it is possible that these indicators will differ significantly across countries and macro regions of the world. In these conditions, the study of the differentiation of package tours and tourist services should not lose its relevance.

\section{References}

Benur, A. M., \& Bramwell, B. (2015). Tourism product development and product diversification in destinations. Tourism Management, 50, 213-224.

https://doi.org/10.1016/j.tourman.2015.02.005

Chamberlin, E. H. (1957). Towards a more general theory of value. Oxford University Press.

Cournot, A. A. (2008). Researches into the mathematical principles of the Theory of Wealth. BiblioLife.

Dussauge, P., \& Garrette, B. (1999). Cooperative strategy: competing successfully through strategic alliances. Wiley.

Edgeworth, F. Y. (1996). Writings in probability, statistics and economics. Edward Elgar Pub.

Erkus-Öztürk, H. (2016). Diversification of hotels in a single-asset tourism city tourism and hospitality management. Emerald Group Publishing Limited.

https://doi.org/10.1108/S1871-317320160000012013

Erkuş-Öztürk, H., \& Terhorst, P. (2018). Economic diversification of a single-asset tourism city: evidence from Antalya. Current Issues in Tourism, 21(4), 422-439. https://doi.org/10.1080/13683500.2015.1091806

Farmaki, A. (2012). A supply-side evaluation of coastal tourism diversification: the case of Cyprus. Tourism Planning \& Development, 9(2), 183-203.

https://doi.org/10.1080/21568316.2011.634431

Fisher, R. (1991). Durable differentiation strategies for services. Journal of Services Marketing, 5(1), 19-28. https://doi.org/10.1108/08876049110035459

García, D., \& Tugores, M. (2013). Differentiation in the tourism sector: an evolutionary analysis. Tourism Economics, 19(5), 1107-1122. https://doi.org/10.5367/te.2013.0330

Gebauer, H., Gustafsson, A., \& Witell, L. (2011). Competitive advantage through service differentiation by manufacturing companies. Journal of Business Research, 64, 1270-1280. https://doi.org/10.1016/j.jbusres.2011.01.015

Hotelling, H. (1932). Edgeworth's taxation paradox and the nature of demand and supply functions. Journal of Political Economy, 40(5). https://doi.org/10.1086/254387
Jevons, W. S. (1871). The theory of political economy. Macmillan \& Co. https://archive.org/details/theoryofpolitica00jevouoft/ page/n9/mode/2up

Lancaster, G., \& Jobber, D. (2009). Selling and sales management (8th ed.). Financial Times Prentice Hall.

Lejarraja, I., \& Walkenhorst, P. (2007). Diversification by deepening linkages with tourism. Proceedings of the World Bank Workshop on Export Growth and Diversification: Pro-Active Policies in the Export Cycle. World Bank.

Marshall, A. (2013). Principles of economics (8th ed.). Palgrave Macmillan. http://www.library.fa.ru/files/Marshall-Principles. pdf

Naipaul, S., \& Parsa, H. G. (2000). Supplementary services as a differentiation strategy. Journal of Quality Assurance in Hospitality \& Tourism, 1(1), 67-80. https://doi.org/10.1300/J162v01n01_05

Phillips, W. (2014). Towards diversification of the tourism sector A recreational demand study of yachting and marina services in the Caribbean. Printed at United Nations. https://repositorio.cepal.org/bitstream/handle/11362/36618/S20131129_ en.pdf? sequence $=1$ \&isAllowed $=y$

Porter, M. (1998). On competition. Oxford University Press.

Robinson, J. (1969). The economics of imperfect competition. Palgrave Macmillan. https://doi.org/10.1007/978-1-349-15320-6

Romão, J., \& Nijkamp, P. (2019). Impacts of innovation, productivity and specialization on tourism competitiveness - a spatial econometric analysis on European regions. Current Issues in Tourism, 22(10), 1150-1169. https://doi.org/10.1080/13683500.2017.1366434

Romão, J., Neuts, B., Nijkamp, P. \& Leeuwen, E. S. (2015). Culture, product differentiation and market segmentation: A structural analysis of the motivation and satisfaction of tourists in Amsterdam. Tourism Economics, 21, 455-474. https://doi.org/10.5367/te.2015.0483

Salop, S. (1981). Strategy, predation, and antitrust analysis. Federal Trade Commission.

Sheng, L. (2011). Specialisation versus diversification: A simple model for tourist cities. Tourism Management, 32, 1229-1231. https://doi.org/10.1016/j.tourman.2010.09.012

Smith, W. R. (1956). Product differentiation and market segmentation as alternative marketing strategies. Journal of Marketing, 21(1), 3-8. https://doi.org/10.2307/1247695

Sraffa, P. (1975). Production of commodities by means of commodities: prelude to a critique of economic theory. Cambridge University Press.

Stigler, G. (1983). The organization of industry. University of Chicago Press.

Sutton, J. (2001). Technology and market structure: theory and history. MIT Press.

Weidenfeld, A. (2018). Tourism diversification and its implications for smart specialisation. Sustainability, 10, 319. https:// doi.org/10.3390/su10020319

World Tourism Organization. (2020). World tourism barometer (No 18, January 2020). https://www.unwto.org/world-tourism-barometer-n18-january-2020 